\title{
A preliminary study of the effects of cold, frozen, or room temperature storage of commercial feeds on growth performance and feed consumption of juvenile rainbow trout (Oncorhynchus mykiss)
}

\section{Soğuk, dondurulmuş veya ortam koşullarında depolanan yemlerin gökkuşağı alabalığı (Oncorhynchus mykiss) yavrularında büyüme performansı ve yem tüketimi üzerindeki etkileri hakkında bir ön çalışma}

\author{
Umar Khan ${ }^{1 *}$ - Kadir Seyhan² \\ 1 Karadeniz Technical University, Institute of Marine Sciences and Technology, 61080, Trabzon, Turkey \\ ${ }^{2}$ Department of Maritime Business Administration, Faculty of Marine Science, Karadeniz Technical University, \\ Trabzon 61530, Turkey
}

Abstract: The storage of commercial feeds in a cool and dry place is a prerequisite management strategy to minimize the deterioration of commercial feeds. This study investigated the effects of feed storage conditions on feed intake and growth performances of juvenile rainbow trout (Oncorhynchus mykiss). A total of 240 juvenile rainbow trout, weighing 8.7-10.5 g, were randomly distributed into four groups. Each group was further subdivided into three replicates with 20 fish in each. The experimental fish were fed to apparent satiation twice daily over a 35 -days period using four commercial feeds previously kept at different storage conditions, i.e., room temperature storage $\left(20.8^{\circ} \mathrm{C}\right)$, cold storage $\left(10^{\circ} \mathrm{C}\right)$, or frozen storages $\left(-1.1^{\circ} \mathrm{C}\right.$ and $\left.-15^{\circ} \mathrm{C}\right)$. The feed utilization was assessed by relative feed intake (RFI\%) and feed conversion rate (FCR), while growth performance was evaluated by the thermal-unit growth coefficient (TGC) and specific growth rate (SGR). The preliminary findings suggest that the food storage conditions did not significantly affect feed intake and growth performance in juvenile rainbow trout. The findings provide practical information for fish farmers in the management of feed storage, which covers a remarkable proportion of the total production costs in aquaculture facilities.

Keywords: Aquafeeds, storage conditions, relative feed intake, growth performance, Oncorhynchus mykiss

Öz: Ticari yemlerin serin ve kuru bir yerde depolanması, yemin bozulma hızının en aza indirilmesi için ön koşul olan bir yönetimdir. Bu çalışmada, oda sıcaklğı̆nda $\left(20.8^{\circ} \mathrm{C}\right)$, soğuk ortamda $\left(10^{\circ} \mathrm{C}\right)$ ve dondurulmuş koşullarda $\left(-1.1^{\circ} \mathrm{C}\right.$ ve $\left.-15^{\circ} \mathrm{C}\right)$ muhafaza edilen yemlerle günde 2 kez doygunluk derecesinde 35 gün süreyle beslenen gökkuşağı alabalığı (Oncorhynchus mykiss) yavrularında büyüme performansı yem tüketim oranları üzerindeki etkileri incelenmiștir. 8,7-10,5 g ağırı̆ı̆ında toplam 240 adet yavru gökkuşağı alabalığı rastgele seçilerek dört gruba ayrımıștı. Her bir grup ayrıca her birinde 20 balık bulunan üç tekrar olacak şekilde ayrımıı̧tır. Yem tüketimi, yüzde yem tüketim oranı (\% RFI) ve yem dönüşüm oranı (FCR) ile değerlendirilirken, büyüme performanı, spesifik büyüme oranı (SGR) ve termal büyüme katsayısı (TGC) ile değerlendirilmiştir. Elde edilen veriler, yem depolama koşullarının gökkuşağı alabalığının yem tüketimi ve büyüme performansları üzerinde önemli derecede etkilemediği kaydedilmiştir. Bu çalışmada elde edilen bulgular, balık çiftliklerinde toplam üretim maliyetinin önemli bir kısmını kapsayan ticari yemlerin depolama yönetiminde üreticiler için pratik bilgiler ortaya koymaktadır.

Anahtar kelimeler: Balık yemi, depolama şartları, yüzde yem tüketimi, büyüme performansı, Oncorhynchus mykiss

\section{INTRODUCTION}

The aquaculture sector plays a vital role in contributing to poverty alleviation, economic development, and food security, representing $\sim 82$ million tonnes of aquatic animal production in 2018 and is projected to increase to 109 million tonnes by 2030 (FAO, 2020). Aquafeeds are one of the most important and relatively expensive aquaculture components, representing about $40 \%-90 \%$ of operating expenditures of fish farms (Rana et al., 2009; Pinfold, 2013; El-Sayed et al., 2015). The prices for different feed raw materials used in aquafeeds have risen considerably over the last decade: fishmeal, soybean meal, corn, and wheat increased by 55 to
225\% (Rana et al., 2009; Wong et al., 2016; Naylor et al., 2021). Consequently, aquafeeds need to be carefully considered and managed for profitable production (FAO, 2020).

The aquafeed production reached 44 million tonnes in 2019 worldwide (Alltech, 2020) and is projected to increase to 82 million tonnes by 2023 (CISION, 2018). Turkey's aquafeeds production rose from 0.59 million tonnes in 2019 to 0.63 million tonnes in 2020 and is projected to increase to 0.90 million tonnes by 2023 (Atalay and Maltaş, 2020; TUYEM, 2021). 
The quality of aquafeeds can be subject to rapid deterioration developing molds if not stored properly (Robb et al., 2013). The lousy storage condition can initiate a repaid oxidization of aquafeeds, increasing the number of peroxides that lead to rancidity in the aquafeeds (Kop et al., 2019). The use of oxidized aquafeed results in retarded growth, poor feed efficiency, lethargy, and anemia, with dark body coloring in farmed fish (Tacon, 1992; Kop et al., 2019). Several biological risk factors have also been identified in the aquaculture industry due to poor storage conditions, such as the nesting of rodents, microorganisms, and human endoparasites, including genetically modified ones in areas where aquafeeds and fish products are stored (Firat et al., 2020). In addition, aquafeeds are highly susceptible to insect infestations during their storage at ambient temperature, causing quantity and quality losses with the passing of time (Smith, 1980; Solomon et al., 2016). Insects attacking stored aquafeeds show a rapidly increasing population at temperatures between $25^{\circ} \mathrm{C}$ to $32^{\circ} \mathrm{C}$ (Smith, 1980; Fields et al., 2012). On the other hand, these insects stop feeding, develop slower, and eventually die at a temperature below $13^{\circ} \mathrm{C}$ (Fields et al., 2012). The storage of aquafeeds at low temperatures can also prolong the shelf life of aquafeeds since low temperatures reduce many of the chemical reactions that occur in feed (Singh and Desrosier, 2018).

Consequently, the storage of aquafeeds at a temperature below $13^{\circ} \mathrm{C}$ will probably restrain insect infestation and retard the rate of various chemical reactions that can damage the quantity and quality of aquafeeds during their storage. However, the water content of aquafeeds may form ice crystals at low temperatures, which may influence the digestive process (dos Santos, 1990; Hui et al., 2006) retarding farmed fish growth. The effects of aquafeeds storage conditions (frozen and non-frozen) on the digestive process have been investigated by Khan and Seyhan (2019) for farmed brook trout. They found no significant effects of storage conditions on the gastric evacuation rates of farmed brook trout. However, data on aquafeed storage conditions' impact on fish growth lack in the published literature. This study thus aimed at filling this knowledge gap by examining the growth performance and feed utilization of juvenile rainbow trout (Oncorhynchus mykiss) fed aquafeeds (hereafter "commercial feeds") kept at different storage conditions (ambient, cold, frozen) have been evaluated.

\section{MATERIALS AND METHODS}

A total of 240 juvenile rainbow trout, weighing $8.7-10.5 \mathrm{~g}$, were obtained from the Sürmene Faculty of Marine Sciences in Trabzon. They were randomly distributed into four groups. Each group was further subdivided into three replicates with 20 fish in each. They were stocked in 12 experimental tanks $(\sim 100 \mathrm{~L})$. Each experimental tank received a constant supply of fresh water at a flow rate of 2.5 $\mathrm{I} / \mathrm{min}$ from a brook, and a continuous air bubbling in each tank ensured oxygen saturation. The experiments were conducted in an indoor environment under ambient water temperatures.

The experimental feeds were stored in two refrigerators equipped with varying ranges of temperature. They were fully adequate for obtaining desired temperatures. One of the refrigerators had two sections with two standard temperature ranges: $10^{\circ} \mathrm{C}$ and $-1.0^{\circ} \mathrm{C}$, while the other was a deep freezer with a single standard temperature of $-15.0^{\circ} \mathrm{C}$. A refrigerator thermometer (TFA 14.4000, TFA Dostmann, Germany) was used to reaffirm the temperatures of the above-mentioned refrigerators. Experimental feeds were first placed in airtight bottles and then stored in the refrigerators for 1 week.

Fish were fed by hand twice a day (08:00 $\mathrm{h}$ and 16:00 $\mathrm{h}$ ) to apparent satiation throughout the feeding period that lasted for 35 days. The fish were fed with one of the four different experimental feeds previously kept at different storage conditions, viz., room temperature storage $\left(20.8 \pm 0.4^{\circ} \mathrm{C}\right)$, cold storage $\left(10^{\circ} \mathrm{C}\right)$, and frozen storage $\left(-1.1^{\circ} \mathrm{C}\right.$ and $\left.-15^{\circ} \mathrm{C}\right)$. The feeds stored at cold and frozen conditions were fed immediately to experimental fish without thawing to defrost.

The uneaten feed (pellets) was carefully siphoned using a water hose without disturbing the experimental fish. The uneaten feed was then dried in an oven (Ecocell Drying Oven, MMM Medcenter, Germany) at $60^{\circ} \mathrm{C}$ until a constant weight was reached. The uneaten feeds ' mass was subtracted from the feed offered to calculate the satiation meal for fish in a tank. The commercial feeds used in this study were acquired from Skretting Aquaculture (www.skretting.com) packed in food-grade oxygen barrier polyethylene/aluminum bags. Their chemical compositions are listed in Table 1. The water temperature and dissolved oxygen of experimental tanks were measured using a $\mathrm{HACH}$ portable multi-meter (HQ40D) twice a day.

Weekly measurements of the total biomass (g) of replicate groups for each tank were performed at 04:00 to 05:00 $\mathrm{h}$ to prevent feeding cessation after weighing. Fish from each replica was carefully transferred into a bucket filled with water (known amount of water in $\mathrm{kg}$ ) to take measurements.

Table 1. Main ingredients and chemical composition of commercial feeds ${ }^{*}$ used in the experiment

$\begin{array}{lr}\text { Nutrient value (\%) } & \\ \text { Crude protein } & 44.0 \\ \text { Crude fat } & 21.0 \\ \text { Crude fiber } & 3.9 \\ \text { Crude ash } & 9.0 \\ & \\ \text { Macro Elements (\%) } & 1.8 \\ \text { Calcium } & 1.0 \\ \text { Phosphorus } & 0.2 \\ \text { Sodium } & \\ \text { Trace Elements }(\mathrm{mg} / \mathrm{kg}) & 80 \\ \text { Iron } & 7 \\ \text { Copper } & 110 \\ \text { Zinc } & \end{array}$

*Skretting Aquaculture (Nutreco Company, Turkey) 


\section{Growth measurements}

The weekly feed consumption was divided by total fish biomass in each tank at the end of the week and then multiplied by 100 to express in percentage to evaluate changes in feed intake (relative feed intake, RFI\%) over the growth period. The values of RFI\% were plotted against time, and their relationship was described by an exponential function that provided the best fit to the data than the linear function.

The feed conversion rate (FCR), specific growth rate (SGR), and thermal-unit growth coefficient (TGC) were estimated using the following equations (Korkut et al., 2007; Karabulut et al., 2011)

$$
\begin{gathered}
\mathrm{FCR}=\frac{\text { Feed eaten by fish }}{\text { Weight gained by fish }} \\
\mathrm{SGR}=\frac{\ln \left(W_{f}\right)-\ln \left(W_{i}\right)}{t} \\
\mathrm{TGC}=\frac{W_{f}^{1 / 3}-W_{i}^{1 / 3}}{\text { temp. }\left({ }^{\circ} \mathrm{C}\right) \times t}
\end{gathered}
$$

where $W_{f}$ is the final total biomass weight of all fish in each tank, $W_{i}$ is the initial total biomass of all fish in each tank weight, $t$ is time (days) between $W_{f}$ and $W_{i}$.

\section{Growth pattern modeling}

The relationship between fish weight and time was described by the linear function: $W=a+\rho t$, and exponential function: $W=a e^{\rho t}$, where $W$ is weight, $t$ is time, $a$ is the intercept, and $\rho$ is the regression slope, which can be considered as a growth rate parameter.

\section{Statistical analysis}

One-way analysis of variance (ANOVA) was used to test significant differences between all groups. The analysis of covariance (ANCOVA) was used to compare the regression slope values $\rho$ estimated from different groups to test significance differences. All statistical analyses were carried out using SigmaPlot version 14, from Systat Software, Inc., San Jose California USA, www.sigmaplot.com.

\section{RESULTS AND DISCUSSION}

The water temperature ranged from 15.1 to $16.2^{\circ} \mathrm{C}$ (mean \pm S.D., $15.4 \pm 0.4$ ), and oxygen saturation was $90.53 \%( \pm 4.45)$. No mortality was observed, and all fish actively fed throughout the feeding experiment.

The RFI\% decreased with fish growth (Figure 1), which was comparable to the findings of Craig et al. (2017). Smaller fish generally require more protein than larger fish and consume a larger amount of meals related to their body size than larger fish (Craig et al., 2017). Consequently, feed intake per body weight often decreases over time as fish grow. In this study, the RFI\% of juvenile rainbow trout showed no significant differences between all experimental groups (Oneway ANOVA, $F_{12,3}=0.229, P=0.874$ ). The relationship between RFI\% and time could thus be described by $\mathrm{FI} \%=$ $33.17 e^{-0.022 t} ; R^{2}=0.98$, where $t$ is time for combined data. This parameterized exponential function was used to provide a curved line for Figure 1 . The RFI\% data from different experimental groups are used together in Figure 1.

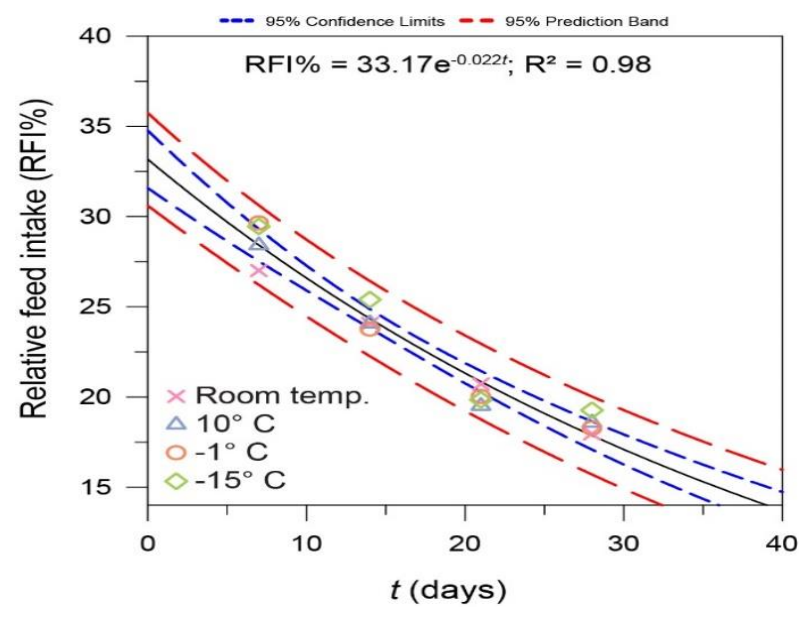

Figure 1. Mean relative feed intake in juvenile rainbow trout (Oncorhynchus mykiss) fed commercial feeds stored at different temperatures.

The results of FCR, SGR, and TGC (mean \pm S.D.) are presented in Table 2. The feed intake and growth performance of juvenile rainbow trout fed either cold, frozen, or non-frozen feeds showed no significant difference between treatments. Likewise, based on weekly data, feed intake and growth performance of different experimental groups also did not reveal any significant difference.

\begin{tabular}{|c|c|c|c|c|c|c|}
\hline \multirow[b]{3}{*}{ Parameter } & \multicolumn{6}{|c|}{ STORAGE CONDITIONS } \\
\hline & \multirow{2}{*}{$\begin{array}{l}\text { Room temperature } \\
20.8( \pm 0.4)^{\circ} \mathrm{C}\end{array}$} & \multirow{2}{*}{$\begin{array}{l}\text { Cold condition } \\
10^{\circ} \mathrm{C}\end{array}$} & \multicolumn{2}{|l|}{ Frozen condition } & \multicolumn{2}{|c|}{ one-way ANOVA } \\
\hline & & & $-1.0^{\circ} \mathrm{C}$ & $-15.0^{\circ} \mathrm{C}$ & $F_{3,8}$ & $P$ \\
\hline TGC & $0.005 \pm 0.000$ & $0.004 \pm 0.000$ & $0.004 \pm 0.000$ & $0.005 \pm 0.000$ & 1.207 & 0.368 \\
\hline SGR & $5.983 \pm 0.044$ & $6.056 \pm 0.030$ & $5.972 \pm 0.095$ & $5.969 \pm 0.051$ & 1.422 & 0.306 \\
\hline FCR & $1.083 \pm 0.026$ & $1.020 \pm 0.018$ & $1.013 \pm 0.022$ & $1.071 \pm 0.068$ & 2.446 & 0.139 \\
\hline$\rho$ & $10.239 \pm 1.549$ & $10.182 \pm 0.912$ & $9.393 \pm 2.529$ & $9.958 \pm 1.803$ & $0.834^{* *}$ & 0.48 \\
\hline
\end{tabular}

Table 2. Summary statistics for growth and feed intake in juvenile rainbow trout (Oncorhynchus mykiss) fed commercial feeds stored at different temperatures.

* Thermal-unit growth coefficient, TGC); standard growth rate, SGR; feed conversion rate, FCR; regression slopes of the linear function, $\rho$ "* $F_{3,68}$, "*simple linear function 
The linear function best described the relationship between fish weight gain and time since it consistently provided a higher value of the coefficient of determination, $R^{2}$, than the exponential function. A positive regression slope value was obtained for each group, indicating increased body weight over time (Figure 2). Based on regression slope values, the growth rates in juvenile rainbow trout fed either cold stored, frozen, or non-frozen feeds did not differ significantly (One-way ANOVA, $F_{3,68}=0.834, P=0.480$ ). The ANCOVA reaffirmed these results and revealed homogeneous slopes suggesting that juvenile rainbow trout from different groups had similar growth rates (ANCOVA, $\left.F_{(3,64)}=0.834, P=0.480\right)$. Several authors have used the ANCOVA to validate the homogeneity of regression slopes estimated for different groups (Gillanders, 1997; Basusta and Khan, 2021). The relationship between fish weight gain and time has been determined using the linear function, exponential function, asymptotic function, and von Bertalanffy growth function (Hopkins, 1992; Hamre et al., 2014).

Fish growth generally has two phases: an initial exponential phase that changes linearly as fish reaches its maximum asymptotic weight (Soderberg, 2017). Such a relationship can appropriately be described by von Bertalanffy growth function (Katsanevakis, 2006; Lugert et al., 2016). However, this study found a linear growth rate in juvenile rainbow trout, which is consistent with previous studies' results (Yakupitiyage et al., 1991; Lugert et al., 2016; Khan, 2019). Consequently, the growth in fish during their initial stage might follow a linear growth trend, followed by an exponential phase that would eventually lead to a relatively linear as a fish achieve a maximum asymptotic weight.
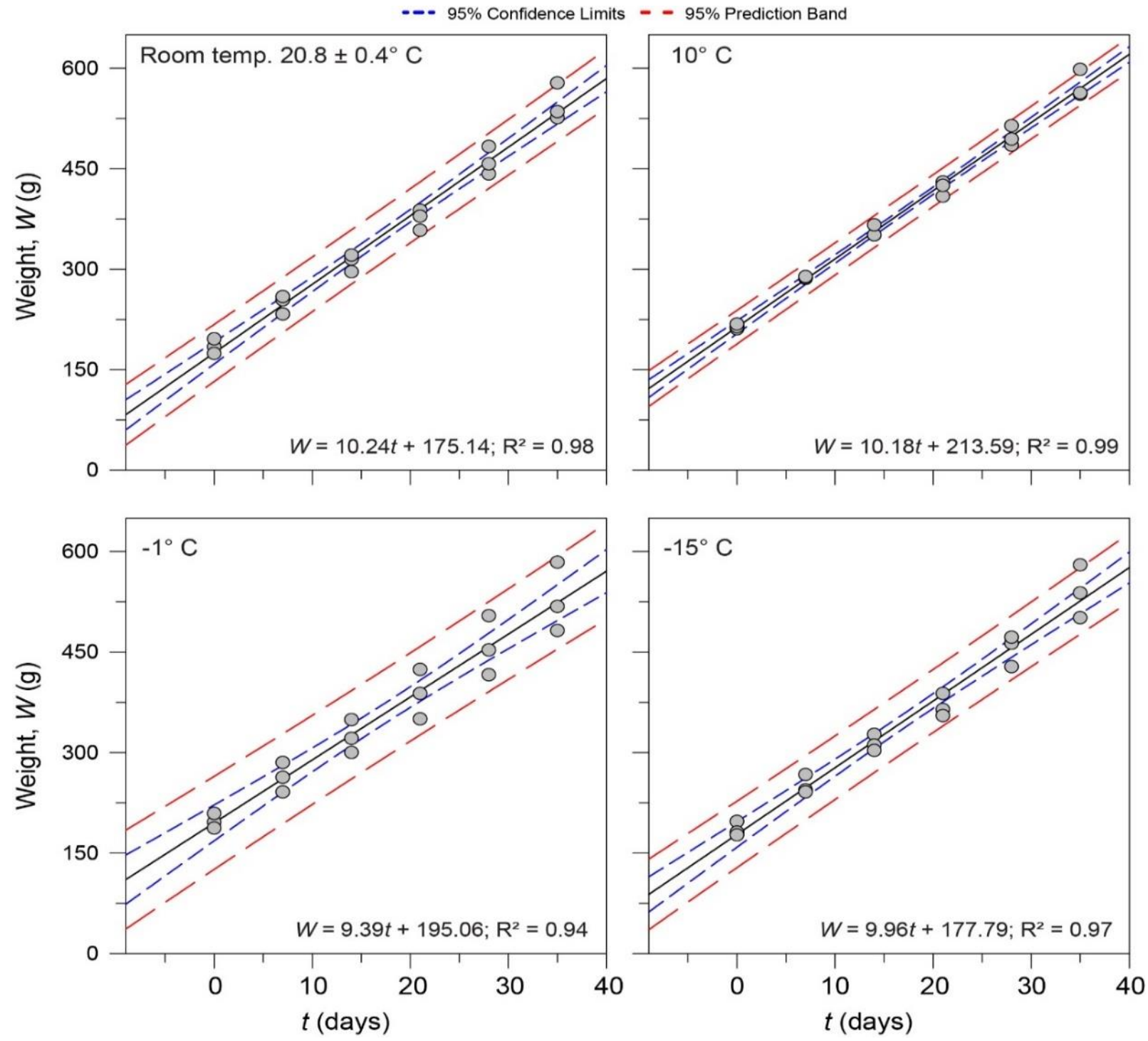

Figure 2. Growth rate of juvenile rainbow trout (Oncorhynchus mykiss) fed commercial feeds stored at different temperatures. 
The water content of commercial feeds could form ice crystals due to the freezing process, which may affect different biochemical and physicochemical processes and may influence the digestive process in the stomach of fish (dos Santos, 1990; Hui et al., 2006). Andersen (2012) fed Atlantic cod Gadus morhua with the previously frozen $\left(-20^{\circ}\right.$ C) and fresh Ammodytes tobianus to examine the possible influence of non-frozen and frozen meals on the gastric evacuation in fish. The author found that both previously frozen and freshly killed $A$. tobianus evacuate at a similar rate from the stomach of G. morhua. Similarly, brook trout (Salvelinus fontinalis) were fed non-frozen and frozen (-15.0 C) feeds; the trout evacuated both meal types with a similar rate of gastric evacuation, indicative of no effect of feed storage on digestive processes (Khan and Seyhan, 2019).

\section{REFERENCES}

Alltech. (2020). 2020 Global Feed Survey. Available online: https://www.alltech.com (accessed on 6 April 2021).

Andersen, N. G. (2012). Influences of potential predictor variables on gastric evacuation in Atlantic cod Gadus morhua feeding on fish prey: parameterization of a generic model. Journal of Fish Biology, 80(3), 595612. DOI:10.1111/j.1095-8649.2011.03195.x

Atalay, M. A. \& Maltaş, Ö. (2020). Aquaculture legislation and management of Turkey. In Çoban, D Demircan, M.D Tosun, D.D. (Eds.), Marine Aquaculture in Turkey: Advancements and Management (pp 304-329). Turkish Marine Research Foundation (TUDAV) Publication No: 59, istanbul, Turkey.

Basusta, N. \& Khan, U. (2021). Sexual dimorphism in the otolith shape of shi drum, Umbrina cirrosa (L.), in the eastern Mediterranean Sea: Fish sizeotolith size relationships. Journal of Fish Biology, 99(1), 164-174. DOI: $10.1111 / \mathrm{jfb} .14708$

CISION. (2018). Global Aquafeed Market 2018-2023. https://www.prnewswire.com/news-releases/global-aquafeed-market2018-2023-300709663.html.

Craig, S., Helfrich, L. A., Kuhn, D. \& Schwarz, M. H. (2017). Understanding fish nutrition, feeds, and feeding. Virginia: College of Agriculture and Life Sciences, Virginia Polytechnic Institute and State University. pp. 420256,

dos Santos, J. (1990). Aspects of the eco-physiology of predation in Atlantic cod (Gadus morhua L.) (PhD Thesis). University of Tromsù, Tromsù, Norway,

El-Sayed, A. F. M., Dickson, M. W. \& El-Naggar, G. O. (2015). Value chain analysis of the aquaculture feed sector in Egypt. Aquaculture, 437, 92101. DOI:10.1016/j.aquaculture.2014.11.033

FAO. (2020). Outlook and emerging issues: In The state of world fisheries and aquaculture 2020: Sustainability in action. Food and Agriculture Organization of the United Nations, pp. 24. DOI:10.4060/ca9231en

Fields, P., Subramanyam, B. \& Hulasare, R. (2012). Extreme temperatures. In Hagstrum, D.W., Phillips, T.W., Cuperus, G. (Eds.), Stored Product Protection. Kansas State Research and Extension, Kansas, pp. 179190. Kansas State University, KSRE Publ.

Fırat, K., Çabuk, A. \& Uyumsal, S. (2020). Occupational health and safety in Turkish marine aquaculture. In Çoban, D Demircan, M.D Tosun, D.D. (Eds.), Marine Aquaculture in Turkey: Advancements and Management (pp 304-329). Turkish Marine Research Foundation (TUDAV) Publication No: 59, İstanbul, Turkey.

\section{CONCLUSION}

The preliminary findings suggest that the growth and feed consumption of juvenile rainbow trout were not affected by the storage conditions of the feed at either cold, frozen, or roomtemperature conditions. Generally, the fish feeds are stored at room temperature for future use. Kop et al. (2019) found that the number of peroxides in feed (lipid) increases with increasing temperature, demonstrating a short shelf life for feed stored at room temperature than samples stored at $4^{\circ} \mathrm{C}$. These findings may provide helpful information for fish farmers in managing feed storage of commercial feeds with prolonging shelf life, which is known to cover a significant amount of the total production costs in the aquaculture industry. This preliminary study included juvenile fish; consequently, subsequent research should include larger size fish coupled with the examination of feed quality properties in order to draw a broader conclusion.

Gillanders, B. M. (1997). Comparison of growth rates between estuarine and coastal reef populations of Achoerodus viridis (Pisces: Labridae). Marine Ecology Progress Series, 146(1-3), 283-287. DOI 10.3354/meps146283

Hamre, J., Johnsen, E. \& Hamre, K. (2014). A new model for simulating growth in fish. PeerJ, 2, e244. DOI:10.7717/peerj.244

Hopkins, K. D. (1992). Reporting fish growth: A review of the basics. Journal of the World Aquaculture Society, 23(3), 173-179.

Hui, Y., Cross, N., Kristinsson, H., Lim, M., Nip, W., Siow, L. \& Stanfield, P. (2006). Biochemistry of seafood processing. In Y. H. Hui (Ed.), Food biochemistry \& food processing (pp. 351-378). Ames, IA: Blackwell Publishing Professional. DOI:10.1002/9781118308035.ch19

Karabulut, H. A., Balta, F., Yandi, I. \& Serezli, R. (2011). The Effects of different levels of ascorbic acid on growth performance and meat composition of brook trout (Salvelinus fontinalis). Kafkas Universitesi Veteriner Fakultesi Dergisi, 17(2), 303-308.

Katsanevakis, S. (2006). Modelling fish growth: Model selection, multi-model inference and model selection uncertainty. Fisheries Research, 81(2-3), 229-235. DOI:10.1016/j.fishres.2006.07.002

Khan, U. (2019). Effects of salinity on brook trout (Salvelinus fontinalis) alevins growth. Journal of Anatolian Environmental and Animal Sciences, 4(2), 93-96. DOI:10.35229/jaes.544375

Khan, U. \& Seyhan, K. (2019). Gastric evacuation evacuation rates in farmed brook trout subjected to a range of feeding conditions fed commercial pellets. Aquaculture, 513, 734390. DOI:10.1016/j.aquaculture.2019.734390

Kop, A., Gamsız, K., Korkut, A. Y. \& Sayğı, H. (2019). The effects of different storage temperatures and durations on peroxide values of fish feed ingredients. Turkish Journal of Agriculture-Food Science and Technology, 7(sp3), 43-49. DOI:10.24925/turjaf.v7isp3.43-49.3154

Korkut, A. Y., Kop, A., Demirtaş, N. \& Cihaner, A. (2007). Balık Beslemede Gelişim Performansının İzlenme Yöntemleri [Determination methods of growth performance in fish feeding]. E.Ü. Su Ürünleri Dergisi [E.U. Journal of Fisheries \& Aquatic Sciences], 24, 201-205

Lugert, V., Thaller, G., Tetens, J., Schulz, C. \& Krieter, J. (2016). A review on fish growth calculation: multiple functions in fish production and their specific application. Reviews in Aquaculture, 8(1), 30-42. DOI:10.1111/raq.12071

Naylor, R. L., Hardy, R. W., Buschmann, A. H., Bush, S. R., Cao, L., Klinger, D. H., ... Troell, M. (2021). A 20-year retrospective review of global aquaculture. Nature, 591(7851), 551-563. DOI:10.1038/s41586-021-03308-6 
Pinfold, G. (2013). Socio-economic Impact of Aquaculture in Canada. Fisheries and Oceans Canada Aquaculture Management Directorate. Gardner Pinfold Consultants Inc., Nova Scotia. pp. 1-16. https://wavesvagues.dfo-mpo.gc.ca/Library/40739016.pdf.

Rana, K. J., Siriwardena, S. \& Hasan, M. R. (2009). Impact of rising feed ingredient prices on aquafeeds and aquaculture production: Food and Agriculture Organization of the United Nations (FAO).

Robb, D. H., Crampton, V. O., Robb, D. \& Crampton, V. (2013). On-farm feeding and feed management: perspectives from the fish feed industry. On-farm feeding and feed management in aquaculture, 489-518.

Singh, R. P. \& Desrosier, N. W. (2018). Food preservation. Encyclopedia Britannica, 28 Sep. 2018, https://www.britannica.com/topic/foodpreservation. Accessed 4 August 2021.

Smith, L. S. (1980). Chapter 13. Storage Problems of Feedstuffs: ADCP/REP/80/11 - Fish Feed Technology. FAO, Fisheries and Aquaculture Department, Rome, Italy.

Soderberg, R. (2017). Aquaculture technology: flowing water and static water fish culture. CRC Press, Boca Raton. p. 284: CRC Press.
Solomon, S., Tiamiyu, L., Okomoda, V. \& Adaga, K. (2016). Nutrient Profile of Commercial Fish Feeds under Different Storage Conditions. International Journal of Aquaculture, 6.

Tacon, A. (1992). Nutritional fish pathology. Morphological signs of nutrient deficiency and toxicity in farmed fish. FAO Fish Technical Paper. No. 330. Rome, FAO. 75 p.

TUYEM. (2021). Production of Compound. Feeds Production (in Turkish). Türkiye Yem Sanayicileri Birliği Dergisi. https://www.yem.org.tr/.

Wong, M. H., Mo, W. Y., Choi, W. M., Cheng, Z. \& Man, Y. B. (2016). Recycle food wastes into high quality fish feeds for safe and quality fish production. Environmental Pollution, 219, 631-638. DOI:10.1016/j.envpol.2016.06.035

Yakupitiyage, A., Edwards, P. \& Wee, K. (1991). Supplementary feeding of fish in a duck- fish integrated system. I. The effect of rice-bran. In: Silva, S.S.D. (Ed.), Fish Nutrition Research in Asia. Proceedings of the Fourth Asian Fish Nutrition Workshop. Asian Fish, Soc. Spec. Publ. 5. Asian Fisheries Society (pp. 143-157). Manila, Philippines. 